Liu, J. \& Alexander, R. (2017). Factors Affecting Faculty Use of Video Conferencing in Teaching: A Mixedmethod Study. Journal of Educational Technology Development and Exchange, 10(2), 37-54.

\title{
Factors Affecting Faculty Use of Video Conferencing in Teaching: A Mixed-method Study
}

\author{
Juhong Christie Liu \\ James Madison University \\ Rob Alexander \\ James Madison University
}

\begin{abstract}
Teaching and learning can now utilize a variety of real-time technologies to build online social presence and learning interactions. However, teachers and students must effectively prepare for this experience; and the identification of contextual and perceptual influences become evolving and necessary (Lehman \& Conceição, 2010; Liu \& Kaye, 2016). In this paper, the authors explore factors that impact faculty use of synchronous video conferencing $(V C)$ in teaching. The two-phase mixed-method study spanned a year, converging qualitative and quantitative approaches through observations and recordings during a 6-week faculty professional development program, a campus-wide survey, and focus groups. Thematic analysis was used for coding qualitative data (Guest, MacQueen, \& Namey, 2012). Descriptive statistics, cross tabulation, logistic regression, and standard multiple regression were used to analyze quantitative data. A model with faculty demographic factors and perceived importance of technology features and quality for teaching was initially developed and tested, which explained $69.1 \%$ of the variance in predicting faculty use of VC technologies in teaching. The perceived importance of VC features and quality scale generated Cronbach's Alpha .866. The study then provides meaningful process and recommendations to define institutional support to the VC adoption in teaching.
\end{abstract}

Keywords: video conferencing in teaching, adoption, pedagogy, value of integration, mixedmethod

\section{Introduction}

As digital technologies become more ubiquitous, faculty members in higher education face the ever-blurrier distinction between face-to-face and computer-mediated pedagogy. The many choices of video conferencing (VC) software and platforms and their evolving features provide opportunities as well as challenges to the research and practice for teaching and learning in online environments (Bower, Dalgarno, Kennedy, Lee, \& Kenney, 2015; Cornelius, 2014). 
VC systems have existed since the early 1980 s and enable users to host a realtime conference across different geographic locations involving both sound and imagery (Bly, Harrison, \& Irwin, 1993; Sabri \& Prasada, 1985). As a learning tool, VC systems offer real-time classroom experience for teachers and students who cannot meet in the same brick-and-mortar classroom (Finkelstein, 2009; Wang, Chen, \& Levy, 2010). Instant communication in audio and video formats between remote locations has great potential for building a learning community that otherwise could not develop; simultaneous presentation and screen sharing allow the remote connectivity among subject experts, students, and lab equipment in distributed locations (Bower et al., 2015). The effective use of $\mathrm{VC}$ in higher education, however, has a mixed trajectory regarding adoption and use (Cornelius, 2014; Huang \& Hsiao, 2012; Martin \& Parker, 2014; Park \& Bonk, 2007a). This creates a need for continued investigation of usage facilitators and barriers.

\section{Literature Context and Conceptual Framework}

As mentioned previously, $\mathrm{VC}$ technology is not a new concept nor a new practice for teaching and learning (Martin, 2005; Sabri \& Prasada, 1985; Wang, 2004; Wang et al., 2010). However, the co-existence of many options of VC technologies and the increased demand of collaborative teaching and learning across disciplines and institutions require new perspectives to maximize effective integration of these tools, particularly regarding faculty adoption (Bower et al., 2015; Capterra, 2017; Estes, Liu, Zha, \& Reedy, 2014; Reid, 2017). In terms of innovative technology adoption in teaching, users are normally driven by a plethora of factors, ranging from values for acceptance, attributes of innovations, and other organization and personal traits. Values for acceptance can include the perception of usefulness and ease of use based on core purposes (Davis, Bagozzi, \& Warshaw, 1989; Davis \& Venkatesh, 1996; Venkatesh \& Davis, 2000). Adopters also evaluate the

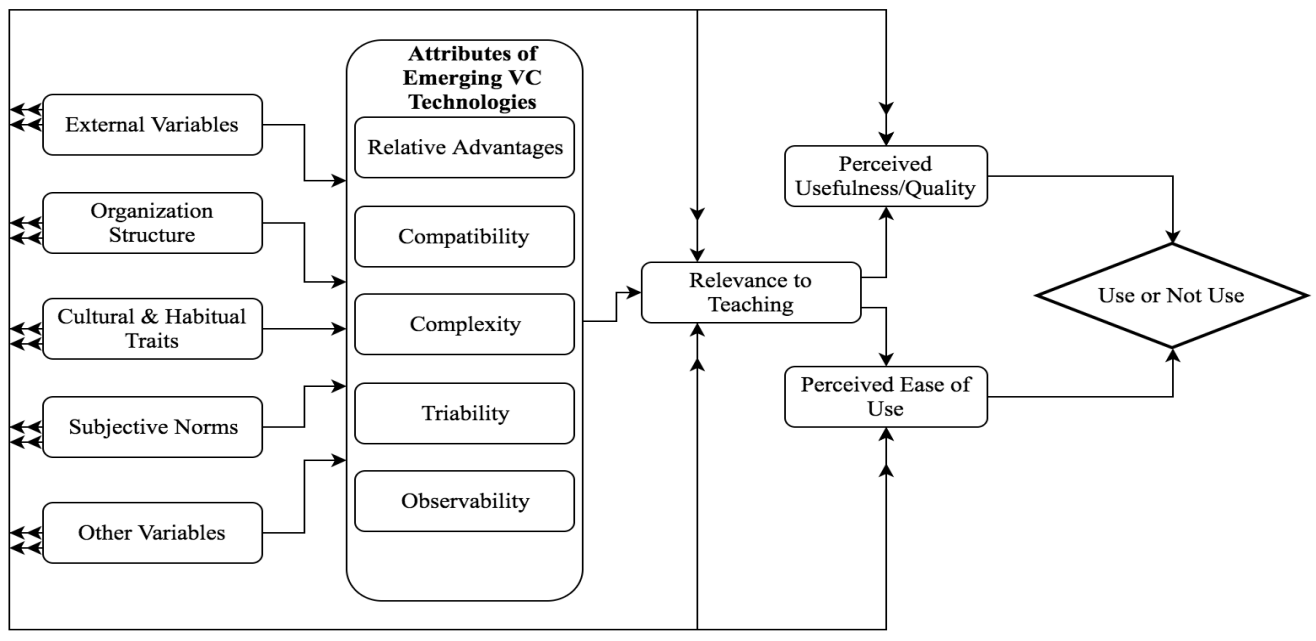

Figure 1. Conceptual framework. 
teaching relevance of innovative attributes offered by emerging technologies, including relative advantages, compatibility, complexity, triability, and observability (Rogers, 2010).

Existing research identifies several facilitators for effective integration, such as adequate student preparation (Bliesener, 2006; Liu \& Kaye, 2016; Park \& Bonk, 2007b), sufficient faculty training regarding both use and pedagogy (Park and Bonk, 2007a), and addressing differential needs stemming from inherent demographic traits and organizational/ cultural characteristics of faculty members that shape personal preferences of technology features and interfacing (Martin and Parker, 2014).

Multiple barriers also exist. These have been associated with the need to adapt to evolving pedagogical practice (Voogt \& Roblin, 2012), academic culture and trend (Cornelius, 2014; Martin, 2005), organizational structure and supportive variables (Schneckenberg, 2009), and demographic factors of faculty members (Martin \& Parker, 2014). Scholars applying the 'technology acceptance model' have identified perceived ease of adoption, perceived usefulness of adoption, and user attitude as key predictors of the integration for new teaching technologies (Davis et al., 1989; Davis \& Venkatesh, 1996; Venkatesh \& Davis, 2000). In addition, evidence tentatively points to additional and specific factors related to organizational structure, cultural and habitual traits, and subjective norms (Bagozzi, 2007; Mathieson, 1991; Schepers \& Wetzels, 2007; Schneckenberg, 2009; Venkatesh \& Davis, 2000). These have led to an evolving conceptual framework depicted in Figure 1. It is through this framework that the researchers implementing this study investigated the pedagogical decisions made by faculty at a US university regarding use of VC technologies.

\section{Research Questions, Research Design, and Data Collection Methods}

With the purpose of improving institutional support for faculty to effectively adopt new pedagogies enabled by technologies, the authors of this paper focus on the exploration of answers to the following research questions:

1. What is the potential of using $\mathrm{VC}$ technologies in teaching and learning? What are the limitations?

2. What factors affect faculty using $\mathrm{VC}$ technologies in their teaching?

The research described here coincided with an evaluation of university support services for instructional design and pedagogical support implemented during an overlap between multiple VC systems on the study campus. To serve the primary goal of conducting needs assessment for service improvement in the higher educational institution, the authors took the perspective from an action research (Fraenkel, Wallen, \& Hyun, 2015; Gall, Gall, \& Borg, 2007). In addition, the potential of multiple representations of VC technologies was found constantly evolving as well as faculty perception of pedagogical choices (Capterra, 2017; Hakkinen \& Hamalainen, 2012). To meet the needs of educational research evidence to inform teaching practice (Borrego \& Henderson, 2014; Means, Toyama, Murphy, Bakia, \& Jones, 2009; Slavin, 2002), the researchers designed the study with a twophase exploratory mixed-method design (Figure 2). The University Institutional Review Board approved this year-long study with its proposed data collection methods, as presented in Table 1.

The study started with an initial exploratory research design followed by 
a phase II of more deductive, explanatory approach (Creswell, 2014; Creswell \& Clark, 2011). Phase I consisted of both qualitative and quantitative data collection. Qualitative data derived from several sources. One source was a six-week faculty professional development workshop where the research team documented faculty participant exploration of four unique VC systems with different computer operating systems and mobile devices. Six faculty members joined the workshop, representing six disciplinary areas, including Political Science, Chemistry and Biochemistry, Communication Studies, Africana Studies, Sociology and Anthropology, and Music. During the workshop series, both participants and coordinating faculty met 150 minutes per week and tested the VC systems with various devices. The four systems included Blackboard Collaborate, Zoom.us, Google Hangout, and CISCO WebEx. Among them, Zoom.us and Google Hangout in the research were the free version; Blackboard Collaborate and WebEx were procured by the higher education institution. The participants tested these systems with standard Windows or Mac laptops, Windows Surface Pro 3 or iPad air 2, and their personal smart phones in the university wireless environment. The researchers took observation notes at the 150 -minute weekly sessions. Some of the sessions were recorded given the technology options and linked from the learning management system, Instructure Canvas. The literature on teaching with VC were also available on Canvas. The participants were expected to complete an online form for evaluating the $\mathrm{VC}$ system at the end of the day. Participants then ranked the perception of these VC systems with the online form and provided additional open-ended comments.

Phase I data were used to inform the development of a questionnaire administered to the larger population of university faculty during Phase II. The questionnaire was designed in two parts. One part for the action research was to inform the institution of programming needs in terms of instructional design, technology and pedagogy support for faculty and students; and the second part was for the investigation of factors that impact faculty use of VC in teaching. The questions were repeatedly checked by instructors who were experienced $\mathrm{VC}$ users to ensure the face validity.

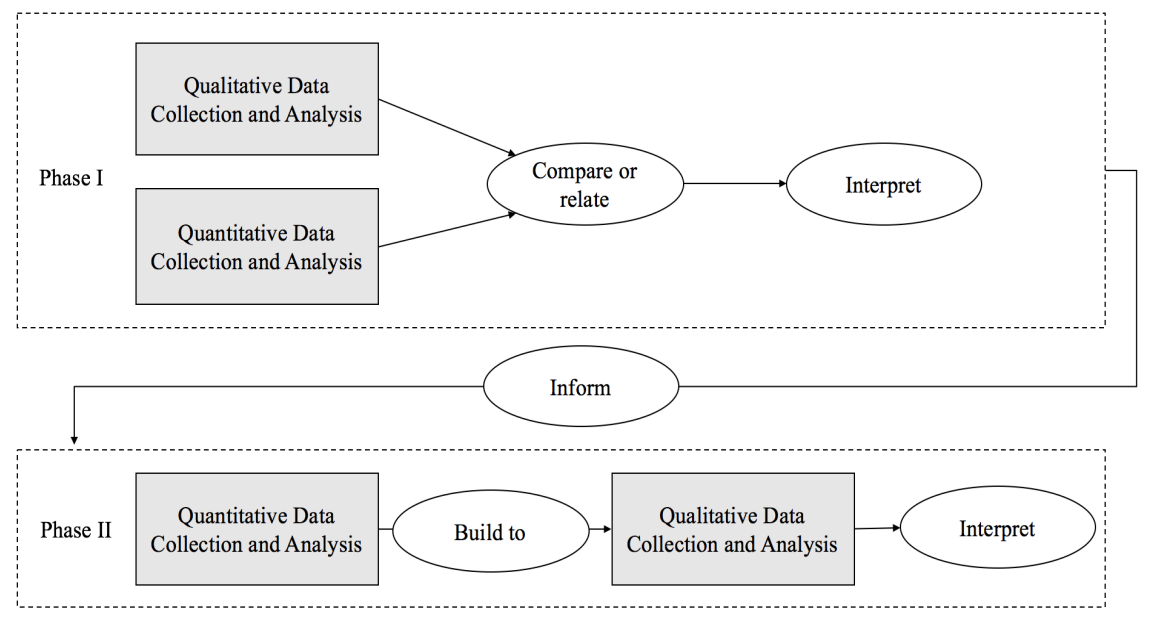

Figure 2. Research design diagram. 
Among the twenty developed questions, eight were about demographics and device use, six were about institution-specific training and support needs, and one about open comments. As an action research, questions about demographics came from both literature and institutional context (Martin \& Parker, 2014; Schneckenberg, 2009). For instance, employ status were listed as: 1) Full-time instructional faculty - tenured; 2) Full-time instructional faculty - pre-tenure; 3) Full time - non-tenure track; 4) Part-time instructional faculty; 5) Administrative and professional faculty.

To investigate factors that would impact faculty use of $\mathrm{VC}$, the researchers developed a question about ranking importance of ten $\mathrm{VC}$ technology features and faculty perceived importance of ease, effectiveness, and efficiency of using $\mathrm{VC}$ in teaching, which is referred to as quality of $V C$ for teaching in the following writing. See Appendix A for the portion of the instrument related to a 'Scale of Faculty Perception of Using VC in Teaching'. In addition, there were three more questions deployed for users and non-users to inform institutional support for teaching with VC. One question was used to differentiate users from non-users of synchronous VC technologies in teaching. For users, one question was about frequency of using $\mathrm{VC}$ and another about challenges when using $\mathrm{VC}$ in teaching; for non-users, one was about support for students and the other about open-ended reasons for not using $\mathrm{VC}$ in teaching.

Because of its action research nature to improve institutional practice, a purposeful sampling within the institution was used for this research (Creswell, 2014; Fraenkel et al., 2015). The Phase II questionnaire was administered to faculty through an online survey system with an email invitation through the campus faculty ListServ. Both quantitative and qualitative data were collected with the online questionnaire. These results were also used to build questions for focus groups that followed the questionnaire responses (Creswell \& Clark, 2011).

During questionnaire implementation, the researchers applied measures to avoid possible survey fatigue as well as to control possible threats to internal validity (Christensen, Johnson, \& Turner, 2010; Fraenkel et al., 2015). By communicating with other stakeholders on campus to plan the timeline of deploying technology-related surveys in the semester, the researchers developed a targeted

Table 1. Research data collection methods, phases, and formats

\begin{tabular}{|l|l|l|}
\hline Data Collection Methods & Data Formats & File Formats \\
\hline Phase $I$ & Qualitative & Notes in text \\
\hline Observation notes & Qualitative & Audio or Video \\
\hline VC Recordings & Quantitative \& Qualitative & Qualtrics \\
\hline VC Evaluation Form & \multicolumn{2}{|l}{} \\
\hline Phase $I I$ & Quantitative \& Qualitative & Qualtrics \\
\hline Campus-wide Questionnaire & Qualitative & Notes in text, audio \\
\hline Faculty Focus Group &
\end{tabular}


timeline for implementation. The questionnaire was then transferred to a web-based survey platform, Qualtrics, and remained active for 5 weeks in the spring semester of 2016 between mid-February and late March. Following the surveys and based on voluntary responses, the researchers conducted two faculty focus groups with five faculty members from Colleges of Business, and Arts and Letters. Finally, targeted member check was applied post-survey and post focus group with specific known users of VC technologies to clarify findings derived from the qualitative data (Creswell, 2014).

\section{Data Analysis}

Because of the diverse nature and purposes of the data collected, data analysis also occurred in two phases as follows.

\subsection{Phase I Data Analysis}

The data derived from the faculty development workshop series indicated the following technology features that would be important for teachers:

- Voice over IP (audio communication among class members) (TechFeature_1)

- Text chat (TechFeature_2)

- Video conferencing with camera view of class members (TechFeature_3)

- Video conferencing with camera view of lab/classroom facility (TechFeature_4)

- Online presentation with slides (TechFeature 5)

- Application sharing (TechFeature_6)

- Participation status (e.g. raising hands) (TechFeature 7)
- Ability to assign moderator role to students (e.g. sharing their screen, presenting from their computers) (TechFeature_8)

- Group work with break-out rooms (TechFeature_9)

- Recording of sessions (TechFeature_10)

Phase I qualitative data revealed several additional usage facilitators based upon the coding and reflection of the observation notes, online activities, and VC session recordings:

Ease of launching and using the VC program, with representative quotes as below:

I liked that I was able to make the interface work, with minimal frustration. I feel confident that I could figure out how to use many features just through exploring the many options available in the pull-down menus.

Record function is easy to use. Reassigning moderator/host is simple to control, managing the participant list is straightforward.

Classroom management with visual presence, with representative quotes as below:

Appears to be a comprehensive application in terms of capabilities for classroom management, with many useful tools embedded and easily accessed through the pull-down menu.

Streamlined organization of facial images through gallery mode, and no apparent issues with lag.

Specific technology features beyond those listed above, with representative quotes as below:

... the automatic conversion of video is 
very useful

This application has full functionality of screen sharing, document sharing, and application sharing that are really easy to switch from one to the other. Also, the potential for students to be the 'drivers' of the session has potential.

I see it being useful for math and science applications where students can demonstrate calculations to the rest of the class

These data also revealed a few challenges regarding adoption of the reviewed technologies:

you would have to be very organized and intentional about using this feature

I find it very complicated and requires a big learning curve to understand

Finally, Phase I data indicated the following features important to faculty when considering the quality or value of integrating $\mathrm{VC}$ technologies into their pedagogical practices:

- Ease of scheduling a synchronous online class session (Quality_1)

- Ease of sharing class materials before the session (Quality_2)

- Ease of sharing class materials during the session (Quality_3)

- Spontaneity in communication (Quality_4)

- Immediacy with audio or video options (Quality_5)

- Ability to provide remote, live demonstrations with equipment not accessible to students (Quality_6)
- Ease of sharing class materials during the session (Quality_3)

- Cost saving in terms of commuting (Quality_7)

- Space saving in terms of physical classroom (Quality_8).

\subsection{Phase II Quantitative Data Analysis}

The online survey was administered through the university bulk email service and was active for 5 weeks, with two email reminders. A total of 105 faculty responses to the survey were received. A data screening was applied to clean missing data before further analysis was conducted, which resulted in 88 valid responses. Among these, 36.4\% responses were from the age group of 41-50, which was followed by those of 51-60 with $22.7 \%$, and those of $30-40$ with $19.3 \%$. $15.9 \%$ of responses were from the age group of 61$70,3.4 \%$ from those over 70 , and $2.3 \%$ from those under 30 (Figure 3).

The responses represented eight colleges across the university, representing unique disciplinary perspectives; $44.3 \%$ of responses came from liberal arts, followed by those from health sciences with $15.9 \%$ and science and math with $13.6 \%, 9.1 \%$ from business and management, $4.6 \%$ from education, $3.4 \%$ from fine arts, and $4.6 \%$ from other units of the university such as the libraries and university studies.

Examining a cross tabulation of age groups and $\mathrm{VC}$ use, 17 of the 41-50 age group indicated their use of $\mathrm{VC}$ in teaching, which was followed by 14 out of 20 from the 5160 age group. Nine responses from both 30 40 and 61-70 age groups indicated the use of VC (Table 2). Among 50 female responses, 33 indicated use $\mathrm{VC}$ technologies in their teaching (Table 3 ). 


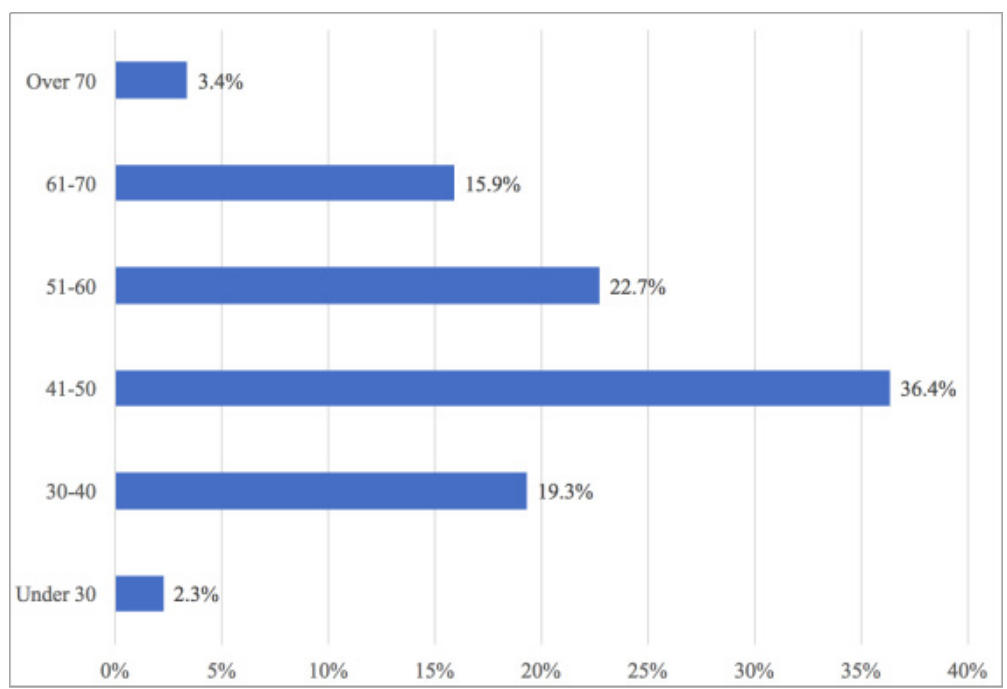

Figure 3. Age distribution of responses.

Table 2. Cross tabulation of age groups and use of VC

\begin{tabular}{|l|r|r|r|r|r|r|r|}
\hline & Under 30 & $30-40$ & $41-50$ & $51-60$ & $61-70$ & Over 70 & Total \\
\hline Not Use & 1 & 8 & 15 & 6 & 5 & 0 & 35 \\
\hline Use & 1 & 9 & 17 & 14 & 9 & 3 & 53 \\
\hline Total & 2 & 17 & 32 & 20 & 14 & 3 & 88 \\
\hline
\end{tabular}

Among the 88 complete responses, 44 indicated themselves as full-time instructional faculty-tenured as employ status, among which 25 used VC in teaching. 19 indicated as pre-tenured which counted toward $21.5 \%$ of the responses, among which 9 used VC in their teaching. The non-tenure track instructional faculty status counted for $17.1 \%$ of the responses with 12 using VC. Nine parttime faculty responded and 6 used $\mathrm{VC}$ in their teaching (Table 4).

Table 3. Cross tabulation of gender and use of VC

\begin{tabular}{|l|r|r|r|}
\hline & \multicolumn{1}{|c|}{ Female } & \multicolumn{1}{|c|}{ Male } & \multicolumn{2}{|c|}{ Total } \\
\hline Not Use & 17 & 18 & 35 \\
\hline Use & 33 & 20 & 53 \\
\hline Total & 50 & 38 & 88 \\
\hline
\end{tabular}


Table 4. Cross tabulation of employ status and use of VC

\begin{tabular}{|c|c|c|c|c|c|c|}
\hline & $\begin{array}{c}\text { Full-time } \\
\text { instructional } \\
\text { faculty - tenured }\end{array}$ & $\begin{array}{c}\text { Full-time } \\
\text { instructional } \\
\text { faculty - Pre-tenured }\end{array}$ & $\begin{array}{c}\text { Full-time } \\
\text { instructional } \\
\text { faculty }- \text { no-tenure } \\
\text { track }\end{array}$ & $\begin{array}{l}\text { Part-time } \\
\text { instructional }\end{array}$ & A/P faculty & Total \\
\hline Not Use & 19 & 10 & 3 & 3 & 0 & 35 \\
\hline Use & 25 & 9 & 12 & 6 & 1 & 53 \\
\hline Total Count & 44 & 19 & 15 & 9 & 1 & 88 \\
\hline$\%$ of Responses & $50.0 \%$ & $21.6 \%$ & $17.1 \%$ & $10.2 \%$ & $1.1 \%$ & \\
\hline
\end{tabular}

Logistic regression was performed to predict $\mathrm{VC}$ use in teaching with the demographic factors of age, college, years of college teaching, employ status, perceived importance of VC technology features, and perceived importance of quality of $\mathrm{VC}$ integration in teaching. The criterion variable was coded as dichotomous, with use of $V C$ in teaching $=1$, not use $V C$ in teaching= 0 . A simultaneous logistic regression was performed for predicting a faculty member's intention to use VC in teaching. The predictor variables included 1) gender, 2) years of teaching, 3) age group, 4) college, 5) employ status, 6) perceived importance of $10 \mathrm{VC}$ technology features rated from $1=$ not important at all to $4=$ very important, 7) perceived importance of quality in the use of $\mathrm{VC}$ for teaching with a set of 8 factors rated from $1=$ not important at all to $4=$ very important. The data of predictor variables were transformed to meet the requirements of logistic regression analysis.

Results of the logistic regression analysis indicate that the 23-predictor model provides a statistically significant improvement over the constant-only model. $X^{2}(23, \mathrm{~N}=65)=$ 47.23, $p<.002$. The Nagelkerke pseudo $\mathrm{R}^{2}$ indicated that the model accounted for $69.1 \%$ of the total variance. This suggests that the set of predictors discriminates between those who use $\mathrm{VC}$ technologies in teaching and those not using VC. Prediction success for the cases used in the development of the model was relatively high, with an overall prediction success rate of $84.6 \%$ and correct prediction rates of $86.1 \%$ for faculty member who use VC in teaching and $82.8 \%$ for those not using $\mathrm{VC}$ in teaching. Table 5 presents the regression coefficients $(B)$, the Wald statistics, significance level, odds ratio $[\operatorname{Exp}(\mathrm{B})]$, and the $95 \%$ confidence intervals (C.I.) for odds ratio $(O R)$ for each predictor.

A standard multiple regression was performed for the frequency of using $\mathrm{VC}$ and perceived challenges in using $\mathrm{VC}$ for teaching by users. Frequency of using $\mathrm{VC}$ in teaching was the dependent variable. The six challenges identified at Phase I were independent variables. As summarized with Table 6, the multiple $\mathrm{R}$ for regression was statistically significant, $F(6,33)=2.45, p<.05, \mathrm{R}^{2}$ adj $=$ .18 . However, the independent variables did not individually contribute significantly to the prediction of frequency of using $\mathrm{VC}$ in teaching. 
Table 5. Logistic regression results for predicting whether a faculty member integrating $V C$ in teaching by using 23 demographic and perception predictors

\begin{tabular}{|c|c|c|c|c|c|c|c|}
\hline \multirow{2}{*}{ Step } & \multirow{2}{*}{ Variable Entered } & \multirow{2}{*}{$B$} & \multirow{2}{*}{ Wald } & \multirow{2}{*}{ Sig. } & \multirow{2}{*}{$\operatorname{Exp}(B)$} & \multicolumn{2}{|c|}{$95 \%$ C.I. for $E X P(B)$} \\
\hline & & & & & & Lower & Upper \\
\hline \multirow[t]{24}{*}{1} & Gender & -.350 & .073 & .787 & .705 & .056 & 8.867 \\
\hline & Years of Teaching & .114 & 1.117 & .291 & 1.121 & .907 & 1.386 \\
\hline & Age & -.375 & .273 & .601 & .688 & .169 & 2.800 \\
\hline & College & .100 & .075 & .785 & 1.105 & .539 & 2.266 \\
\hline & EmployStatus & 1.557 & 4.742 & $.029 * *$ & 4.747 & 1.169 & 19.283 \\
\hline & TechFeature_1 & -.367 & .193 & .661 & .693 & .134 & 3.574 \\
\hline & TechFeature_2 & .483 & .366 & .545 & 1.621 & .339 & 7.758 \\
\hline & TechFeature_3 & -2.276 & 4.551 & $.033 * *$ & .103 & .013 & .831 \\
\hline & TechFeature_4 & 1.340 & 2.385 & .122 & 3.817 & .697 & 20.892 \\
\hline & TechFeature_5 & 3.181 & 3.648 & $.056^{*}$ & 24.067 & .920 & 629.573 \\
\hline & TechFeature_6 & -1.758 & 3.126 & $.077 *$ & .172 & .025 & 1.210 \\
\hline & TechFeature_7 & -1.583 & 1.396 & .237 & .205 & .015 & 2.836 \\
\hline & TechFeature_8 & -1.037 & 1.454 & .228 & .355 & .066 & 1.913 \\
\hline & TechFeature_9 & 2.069 & 3.321 & $.068^{*}$ & 7.919 & .855 & 73.312 \\
\hline & TechFeature_10 & -1.065 & 2.077 & .150 & .345 & .081 & 1.467 \\
\hline & Quality_1 & 2.921 & 2.936 & $.087 *$ & 18.558 & .657 & 524.132 \\
\hline & Quality_2 & .868 & .550 & .458 & 2.383 & .240 & 23.632 \\
\hline & Quality_3 & .692 & .308 & .579 & 1.997 & .173 & 23.022 \\
\hline & Quality_4 & -.972 & .644 & .422 & .378 & .035 & 4.069 \\
\hline & Quality_5 & .713 & .298 & .585 & 2.041 & .158 & 26.408 \\
\hline & Quality_6 & -1.879 & 2.896 & $.089 *$ & .153 & .018 & 1.330 \\
\hline & Quality_7 & -1.977 & 4.253 & $.039 * *$ & .138 & .021 & .906 \\
\hline & Quality_8 & 1.540 & 2.299 & .129 & 4.666 & .637 & 34.174 \\
\hline & Constant & -9.168 & 1.894 & .169 & .000 & & \\
\hline
\end{tabular}

$(* *=$ significant at the .05 level; $*=$ significant at the .10 level $)$ 
Table 6. Regression analysis summary of predicting frequency of using VC in teaching by challenges perceived when teaching with $V C$

\begin{tabular}{|l|r|r|r|}
\hline Variable & $\boldsymbol{B}$ & $\boldsymbol{S E B}$ & $\boldsymbol{\beta}$ \\
\hline Number of configuration steps & .611 & .406 & .283 \\
\hline Bandwidth requirement & -.600 & .389 & -.307 \\
\hline Lack of training & .065 & .385 & .032 \\
\hline Time required to practice & -.094 & .354 & -.051 \\
\hline Lack of time to incorporate & .638 & .323 & .371 \\
\hline Scheduling challenge & .480 & .371 & .215 \\
\hline
\end{tabular}

The Scale of Perceived Importance in Technology Features and Quality of VC Technologies in Teaching (Appendix A) resulted with Cronbach's Alpha of .866 for the 18-question scale, with Cronbach's Alpha of .864 for the Technology Feature subscale, and .774 for the VC Quality for Teaching subscale.

\subsection{Phase II Qualitative Data Analysis}

Qualitative data were documented with the open comments from the surveys, notes and audio recordings from the focus groups. These were coded with the qualitative analysis software, Nvivo. Themes emerged from the coding and categorization as nodes (Fraenkel et al., 2015; Guest et al., 2012). Because of the nature of action research, the nodes were defined based on the literature and research context, as illustrated with the following examples:

Perceived value of integration

I think it's important to see members of a group to understand how people are reacting. It's just convenient to show slides (with a white board function).
Perceived value of integration Collaborative teaching and learning possibilities

The chat works most effectively if the course is team taught with one faculty member monitoring chat (questions, entries, etc) while the other conducts the audio/visual synchronous session.

Students deliver presentations (both individual and group) in live sessions with classmates as audience members.

Technology features and perceived value of integration

Multiple cameras permit all members of a group 'face time' AND permit members of the class to serve as visible audience members. This enhances the transactional nature of communication we value.

The text box and raising hands permits those without the microphone to request a turn.

Limits of technology features

Since I am working to develop the ability 
to use an iPad to facilitate high-quality synchronous sessions, it was disappointing that a) there is no record feature, meaning that one of the features that seems best, recording and then being able to share that on Canvas (or elsewhere) is not available

iPad (and smartphone) users are not able to view shared web content that is viewed within WebEx. However, the iPad was able to view a shared browser.

iPad (and smartphone) users have limited functionality regarding interactivity with presentations. For example, I could not figure out how to contribute to the whiteboard, even when I was assigned the presenter role on the iPad.

\section{Scheduling}

scheduling in summer -- too many time zones and work schedules with 25 students
Ability to teach on snow days rather than schedule a Saturday makeup

Perceived value of integration Sustainability of student-content interaction

Recording of sessions permits students not in attendance during the session to review the session.

Perceived value of integration -Options to allow critical thinking

recording student presentations allows self-critique.

The cluster analysis of nodes was performed to explore the word similarity associated with and between the nodes, as visualized with Figure 4. Pearson correlation coefficient was applied to calculate the similarity (QSR International, 2017). "Cluster analysis is a quantitative tool that has the

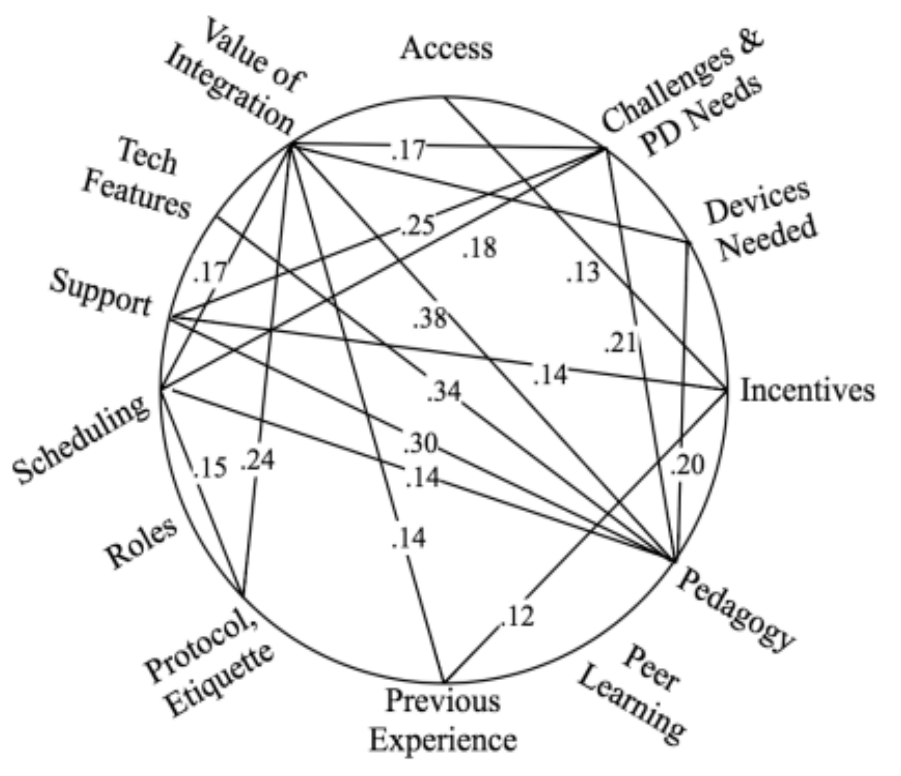

Figure 4. Cluster analysis diagram of nodes. 
potential to help researchers working with the breadth and wealth of data that qualitative inquiry produces." (Macia, 2015, p.1092). The cluster analysis of nodes revealed that there was a high word similarity between anticipated pedagogy and perceived value of integration, with Pearson's correlation coefficient $(r)=.38$, between anticipated pedagogy and perceived technology features $(r=.34)$, between anticipated pedagogy and support $(r=.30)$, between anticipated support and perceived challenges with professional development needs $(r=.25)$.

\section{Results and Discussion}

In this project, the researchers developed a mixed-method approach for understanding the potential of $\mathrm{VC}$ technologies for teaching and factors that shape faculty adoption and use of VC technologies. An immersive professional development for faculty that lasted several weeks and provided a variety of facility and platform options helped identify the technology potential, define the current context for pedagogy updates and related technology selection (Huang \& Hsiao, 2012; Martin \& Parker, 2014; Park \& Bonk, 2007a, $2007 \mathrm{~b}$ ). The analysis of qualitative data identified the potential of $\mathrm{VC}$ technologies for teaching in the institutional context, which answered Research Question 1. The results also identified strong relationships between anticipated pedagogy and perceived value of integration, pedagogy and technology features, pedagogy and support, and between support and perceived challenges and professional development needs. This provided researchbased information for the institution to modify programming and services.

The statistical results generated from a logistics regression initially provided a model to predict faculty members' use of VC based upon their gender, age, years of college teaching, colleges as disciplinary areas, employ status, perception of importance of technology features, and perceived importance of VC quality integration in their pedagogical practice. The set of variables as in the model accounted for $69.1 \%$ of the total variance, with statistical significance. The Wald test reported that three predictors, including employ status, video conferencing with camera view of class members, and cost saving in terms of commuting, were statistically significant $(p<$ .05 ) individual predictors of using $\mathrm{VC}$ in teaching.

These variables map to elements within our conceptual model presenting in Figure 1 related to organizational structure (employment status), subjective norms (cost savings/efficiency), and the relative advantages of seeing students via video features while realizing the advantages of cost savings from not commuting and not using physical classroom space and facilities. For instance, strategies for possible increase of faculty adoption can include increasing incentives or recognition for un-tenured faculty members to gain $\mathrm{VC}$ teaching competency, sharing learning community building with video views of remote class members, and return on investment (ROI) comparison between physical class facility use and VC-enabled synchronous classes.

This study extended the findings in previous studies (Martin \& Parker, 2014; Park \& Bonk, 2007a). The Scale of Perceived Importance in Technology Features and Quality of VC Technologies in Teaching (Appendix A)can be used to define specific ways to support faculty use of $\mathrm{VC}$ technologies through training that is sensitive to pedagogical selection. For instance, this current study has also identified the functionality of mobile devices, not including Windows Surface, as participatory 
(not moderating) tools of $\mathrm{VC}$ in teaching and learning. This finding provides specific recommendations for technology selections for teachers and students in a synchronous VC environment.

The study is not without limitation. The data collection had to utilize a purposeful sampling at one institution and with specific VC technology options, limiting the generalizability of results. However, the authors believe that these findings can inform future directions of research. For instance, future studies should aspire to further validate the data collection instruments used here. Also, future studies should continue to explore institutional decision-making in terms of VC technology selection and programming support for innovative teaching.

\section{Acknowledgements}

We would like to thank the Libraries and Educational Technologies in James Madison University for providing the funding and support for this year-long research project. We would also like to thank the participation in developing the questionnaire, and conducting faculty focus group from the collaborators, Dr. Matt Brigham, Dr. Shenghua Zha, and Ms. Karina Kline-Gabel. The transcription by Ms. Taylor Miller is also greatly appreciated. We would also like to thank all the participating faculty and students who shared their experience and insights with us.

\section{References}

Bagozzi, R. P. (2007). The legacy of the Technology Acceptance Model and a proposal for a paradigm shift. Journal of the Association for Information Systems, 8(4), 244-254.

Bliesener, T. (2006). Training synchronous collaborative e-Learning. International Journal on ELearning, 5(2), 185-196.

Bly, S. A., Harrison, S. R., \& Irwin, S. (1993). Media spaces: bringing people together in a video, audio, and computing environment. Communications of the $A C M, 36(1), 28-46$.

Borrego, M., \& Henderson, C. (2014). Increasing the use of evidence-based teaching in STEM higher education: A Comparison of Eight Change Strategies. Journal of Engineering Education, 103(2), 220-252.

Bower, M., Dalgarno, B., Kennedy, G. E., Lee, M. J. W., \& Kenney, J. (2015). Design and implementation factors in blended synchronous learning environments: Outcomes from a cross-case analysis. Computers \& Education, 86, 1-17.

Capterra. (2017). Top web conferencing software - Compare reviews. Retrieved December 25, 2017, from https://www. capterra.com/web-conferencing-software/

Christensen, L. B., Johnson, R. B., \& Turner, L. A. (2010). Research methods, design, and analysis. Prentice Hall.

Cornelius, S. (2014). Facilitating in a demanding environment: Experiences of teaching in virtual classrooms using web conferencing. British Journal of Educational Technology, 45(2), 260-271.

Creswell, J. W. (2014). Research design: Qualitative, quantitative, and mixed methods approaches.Sage Publications.

Creswell, J. W., \& Clark, V. L. P. (2011). Designing and conducting mixed methods 
research. Sage Publications.

Davis, F. D., Bagozzi, R. P.,\& Warshaw, P. R. (1989). User acceptance of computer technology: A comparison of two theoretical models. Management Science, 35(8), 982-1003.

Davis, F. D., \& Venkatesh, V. (1996). A critical assessment of potential measurement biases in the technology acceptance model: three experiments. International Journal of Human-Computer Studies, 45(1), 19-45.

Estes, M. D., Liu, J., Zha, S., \& Reedy, K. (2014). Designing for problem-based learning in a collaborative STEM lab: A case study. TechTrends, 58(6), 90-98.

Finkelstein, J. (2009). Learning in real time: Synchronous teaching and learning online. John Wiley \& Sons.

Fraenkel, J., Wallen, N., \& Hyun, H. (2015). How to design and evaluate research in education. Mcgraw-Hill Education.

Gall, M. D., Gall, J. P., \& Borg, W. R. (2007). Educational research: An introduction. Pearson.

Guest, G., MacQueen, K. M., \& Namey, E. E. (2012). Applied thematic analysis. Sage Publications.

Hakkinen, P., \& Hamalainen, R. (2012). Shared and personal learning spaces: Challenges for pedagogical design. Internet and Higher Education, 15(4), 231-236.

Huang, X., \& Hsiao, E.-L. (2012). Synchronous and Asynchronous Communication in an Online Environment: Faculty Experiences and Perceptions. Quarterly Review of Distance Education, 13(1), 15-30.

Lehman, R. M., \& Conceição, S. C. (2010). Creating a sense of presence in online teaching: How to "be there" for distance learners (Vol. 18). San Francisco, CA:
John Wiley \& Sons.

Liu, J. C., \& Kaye, E. (2016). Preparing online learning readiness with learner-content interaction: Design for scaffolding selfregulated learning. In L. Kyei-Blankson, J. Blankson, E, Ntuli and C. Agyeman Eds. Handbook of Research on Strategic Management of Interaction, Presence, and Participation in Online Courses, (pp. 216-243). IGI Global.

Macia, L. (2015). Using clustering as a tool:Mixed methods in qualitative data analysis. The Qualitative Report, 20(7), 1083-1094.

Martin, F., \& Parker, M. A. (2014). Use of synchronous virtual classrooms: Why, who, and how? MERLOT Journal of Online Learning and Teaching, 10(2). 192-210.

Martin, M. (2005). Seeing is believing: the role of videoconferencing in distance learning. British Journal of Educational Technology, 36(3), 397-405.

Mathieson, K. (1991). Predicting user intentions: Comparing the Technology Acceptance Model with the Theory of Planned Behavior. Information Systems Research, 2(3), 173-191.

Means, B., Toyama, Y., Murphy, R., Bakia, M., \& Jones, K. (2009). Evaluation of evidence-based practices in online learning: A meta-analysis and review of online learning studies. US Department of Education. Retrieved from http://www. ed.gov/rschstat/eval/tech/evidence-basedpractices/finalreport.pdf

Park, Y. J., \& Bonk, C. J. (2007a). Is online life a breeze? A case study for promoting synchronous learning in a blended graduate course. MERLOT Journal of Online Learning and Teaching, 3(3), 307323.

Park, Y. J., \& Bonk, C. J. (2007b). Synchronous Learning Experiences: Distance and Residential Learners' Perspectives in a 
Blended Graduate Course. Journal of Interactive Online Learning, 6(3), 245264.

QSR International. (2017). NVivo 11 for Windows Help - About cluster analysis. Retrieved December 27, 2017, from http:// help-nv11.qsrinternational.com/desktop/ concepts/about_cluster_analysis.htm

Reid, P. (2017). Supporting faculty adoption of technology: What can we do? EDUCAUSE Review, February 27. Retrieved from https://er.educause. edu/articles/2017/2/supporting-facultyadoption-of-technology-what-can-we-do

Rogers, E. M. (2010). Diffusion of innovations, 4th Edition. Simon and Schuster.

Sabri, S., \& Prasada, B. (1985). Video conferencing systems. Proceedings of the IEEE, 73(4), 671-688.

Schepers, J., \& Wetzels, M. (2007). A metaanalysis of the Technology Acceptance Model: Investigating subjective norm and moderation effects. Information \& Management, 44(1), 90-103.

Schneckenberg, D. (2009). Understanding the real barriers to technology-enhanced innovation in higher education. Educational Research, 51(4), 411-424.

Slavin, R. E. (2002). Evidence-Based education policies: Transforming educational practice and research. Educational Researcher, 31(7), 15-21.

Venkatesh, V., \& Davis, F. (2000). Theoretical extension of the Technology Acceptance Model: Four longitudinal field studies. Management Science, 46(2), 186-204.

Voogt, J., \& Roblin, N. P. (2012). A comparative analysis of international frameworks for 21 st century competences: Implications for national curriculum policies. Journal of Curriculum Studies, 44(3), 299-321.

Wang, Y. (2004). Distance language learning: Interactivity and fourth-generation Internet-based videoconferencing.
CALICO Journal, 21, 373-395.

Wang, Y., Chen, N.-S., \& Levy, M. (2010).

Teacher training in a synchronous cyber face-to-face classroom: Characterizing and supporting the online teachers' learning process. Computer Assisted Language Learning, 23(4), 277-293.

\section{Contact the Author}

\section{Juhong Christie Liu}

James Madison University

Assistant Professor/Senior Instructional Designer

Libraries and Educational Technologies (LET)

Graduate Instructor, Graduate School/

College of Education,

Email:liujc@jmu.edu

\section{Rob Alexander}

James Madison University

Associate Professor

JMU Political

Science Department,

Email: alexanrw@jmu.edu 
Appendix A. Scale of Perceived Importance in Technology Features and Quality of VC Technologies in Teaching

Please rate the importance of the following video conferencing technology features when considering use of a specific technology for teaching.

\begin{tabular}{|c|c|c|c|c|}
\hline & $\begin{array}{l}\text { Not important } \\
\text { at all (1) }\end{array}$ & $\begin{array}{c}\text { Slightly } \\
\text { important (2) }\end{array}$ & $\begin{array}{l}\text { Moderately } \\
\text { important (3) }\end{array}$ & Very important (4) \\
\hline $\begin{array}{l}\text { Voice over IP } \\
\text { (audio communication } \\
\text { among class members) }\end{array}$ & $\mathrm{O}$ & $\mathrm{O}$ & $\mathrm{O}$ & $\mathrm{O}$ \\
\hline Text chat & $\mathrm{O}$ & $\mathrm{O}$ & $\mathrm{O}$ & $\mathrm{O}$ \\
\hline $\begin{array}{l}\text { Video conferencing } \\
\text { with camera view of } \\
\text { class members }\end{array}$ & $\mathrm{O}$ & $\mathrm{O}$ & $\mathrm{O}$ & $\mathrm{O}$ \\
\hline $\begin{array}{l}\text { Video conferencing } \\
\text { with camera view of } \\
\text { lab/classroom facility }\end{array}$ & $\mathrm{O}$ & $\mathrm{O}$ & $\mathrm{O}$ & $\mathrm{O}$ \\
\hline $\begin{array}{l}\text { Online presentation } \\
\text { with slides }\end{array}$ & $\mathrm{O}$ & $\mathrm{O}$ & $\mathrm{O}$ & $\mathrm{O}$ \\
\hline Application sharing & O & $\mathrm{O}$ & $\mathrm{O}$ & $\mathrm{O}$ \\
\hline $\begin{array}{l}\text { Participation status } \\
\text { (e.g. raising hands) }\end{array}$ & $\mathrm{O}$ & $\mathrm{O}$ & $\mathrm{O}$ & $\mathrm{O}$ \\
\hline $\begin{array}{l}\text { Ability to assign } \\
\text { moderator role to } \\
\text { students (e.g. sharing } \\
\text { their screen, presenting } \\
\text { from their computer) }\end{array}$ & $\mathrm{O}$ & $\mathrm{O}$ & $\mathrm{O}$ & $\mathrm{O}$ \\
\hline $\begin{array}{l}\text { Group work with } \\
\text { break-out rooms }\end{array}$ & $\mathrm{O}$ & $\mathrm{O}$ & $\mathrm{O}$ & $\mathrm{O}$ \\
\hline Recording of sessions & O & O & $\mathrm{O}$ & $\mathrm{O}$ \\
\hline
\end{tabular}


Please rank the importance of the following qualities in a video conferencing technology for your teaching.

\begin{tabular}{|c|c|c|c|c|}
\hline & $\begin{array}{l}\text { Not important } \\
\text { at all (1) }\end{array}$ & $\begin{array}{c}\text { Slightly } \\
\text { important (2) }\end{array}$ & $\begin{array}{c}\text { Moderately } \\
\text { important (3) }\end{array}$ & Very important (4) \\
\hline $\begin{array}{l}\text { Ease of scheduling a } \\
\text { synchronous online } \\
\text { class session }\end{array}$ & $\mathrm{O}$ & $\mathrm{O}$ & $\mathrm{O}$ & $\mathrm{O}$ \\
\hline $\begin{array}{l}\text { Ease of sharing class } \\
\text { materials before the } \\
\text { session }\end{array}$ & $\mathrm{O}$ & $\mathrm{O}$ & $\mathrm{O}$ & $\mathrm{O}$ \\
\hline $\begin{array}{l}\text { Ease of sharing class } \\
\text { materials during the } \\
\text { session }\end{array}$ & $\mathrm{O}$ & $\mathrm{O}$ & $\mathrm{O}$ & $\mathrm{O}$ \\
\hline $\begin{array}{l}\text { Spontaneity in } \\
\text { communication }\end{array}$ & $\mathrm{O}$ & $\mathrm{O}$ & $\mathrm{O}$ & $\mathrm{O}$ \\
\hline $\begin{array}{l}\text { Immediacy with audio } \\
\text { or video options }\end{array}$ & $\mathrm{O}$ & $\mathrm{O}$ & $\mathrm{O}$ & $\mathrm{O}$ \\
\hline $\begin{array}{l}\text { Ability to provide } \\
\text { remote, live } \\
\text { demonstrations with } \\
\text { equipment not } \\
\text { accessible to students }\end{array}$ & $\mathrm{O}$ & $\mathrm{O}$ & $\mathrm{O}$ & $\mathrm{O}$ \\
\hline $\begin{array}{l}\text { Cost saving in terms } \\
\text { of commuting }\end{array}$ & $\mathrm{O}$ & $\mathrm{O}$ & $\mathrm{O}$ & $\mathrm{O}$ \\
\hline $\begin{array}{l}\text { Space saving in } \\
\text { terms of physical } \\
\text { classroom }\end{array}$ & $\mathrm{O}$ & $\mathrm{O}$ & $\mathrm{O}$ & $\mathrm{O}$ \\
\hline
\end{tabular}

